\title{
REPORT OF THE PRESIDENT OF THE INTERNATIONAL MEDICAL SOCIETY OF PARAPLEGIA, SIR GEORGE BEDBROOK, O.B.E., F.R.C.S., TO THE ANNUAL GENERAL MEETING, MAY I983; STOKE MANDEVILLE HOSPITAL, AYLESBURY, ENGLAND
}

I HAVE CONTINUED to peruse the aims I expressed since elected to office:

(a) To extend the Society's work in countries where development is needed.

(b) To improve Membership.

(c) To consider areas where change in the Society's activities are required.

During the 7 months since we last met, communication has been my major activity. Even although we live and work great distances apart there is no reason nowadays for poor contacts. I hope I have made this abundantly clear to all by telephone, telex, correspondence and meetings.

I have on your behalf visited Hong Kong this year; buildings are underway and interest has been rekindled in the area of Spinal Injury. I also visited Vienna and participated in the International College of Surgeons Meeting but I would not regard the system of care in Austria as ideal and had discussions in this regard. Correspondence has been extensive and interesting. Most of this will become evident during this meeting at Stoke Mandeville but I shall list some of it to exemplify my opening remarks.

I. Correspondence has developed with colleagues in this Society regarding learned societies pertaining to Spinal Injuries in Africa, India, Japan, Indonesia, in four of five countries in Europe, North America and finally Australia and New Zealand.

2. I have opened communications with our members and others in Brazil, Argentina, Costa Rica, Qatar, Saudi Arabia, Soviet Russia, Papua New Guinea, Taiwan, Thailand and Burma.

3. Correspondence and telephone discussion and face to face discussions about an important development in China have started.

4. Our previous Vice President, Mr Ellis Griffiths, is now President of the Western Pacific Orthopaedic Association. At the conference in Perth last year many contacts were made which I know will be followed up when the Spinal Section of that body meets in Tokyo in October of this year.

5. Dr Albert Tricot, one of our Past Presidents, has been elected President of Association Francophone Internationale de Groupes d'Animation de la Paraplegié A.F.I.G.A.P.

I would like to thank those members who have thought about and written to me about matters of:

(a) Regional representation;

(b) Vice Presidents (numbers and responsibilities);

(c) Regional Finance;

(d) Reorganisation of Secretarial Responsibilities. 
There are matters needing further discussion and then decision for executive action.

My review of the Constitution as it affects Council now awaits discussion by the Executive and then by the Council. I have had contact with W.H.O. and the United Nations via Professor Pierre Minaire and expect this to develop further. Contact has been furthered with the Council for International Organisations in Medical Science.

Through Dr Cairbre McCann, Chairman of the Medical Committee of the International Stoke Mandeville Games and personal contact with the President, Dr Robert Jackson I have kept in contact with developments and am delighted to learn of the Dr Van D. Maas Memorial Sports Medicine Symposium to be inaugurated this year; the functional classification of sportsmen is now being examined carefully; and also the possibility of our having Combined Sessions in 1984. The apparent dominance of Wheelchair Basketballers does not please me; such prima donna attitudes may lead to problems.

Our Scientific.Conferences need improving, with Special Lectures such as we will have at this Meeting, possibly Instructional Course Lectures, a session on Current Research, as well as Posters and good Trade Exhibits. Our secretariat have carried this burden too long and I hope that a small Scientific Committee can be considered.

I would like to thank the members who helped me to think further on having a Certificate of Competency; that is, of official recognition.

Finally, let me thank the present Vice Presidents and the Past Officers for their help.

The Secretariat have constantly been in communication as is only right and proper; I intented to be a 'working' President, I thank them for their help.

Phillip Harris and I have a thick file on all sorts of matters; the aim is further improvement of the Journal. For those like Mr Jim Cosbie Ross, Dr Alan Hardy and Professor Alain Rossier and others involved in the Journal, and to all of the Editorial Board, I say thank you for your impressive efforts regarding the Journal. Journal utilisation is on the increase and yet needs more work. You all know the statement 'By their deeds ye shall know them'; this is one of our deeds. I will be visiting the new spinal injury services in the United Kingdom; in London and in Salisbury.

We have a challenging 15 months in front of us before our next major meeting. I look forward to the intervening meetings both scientific and administrative to further our goals and to fulfil the objects of our constitution. 